\title{
The role of Praseodymium oxide-Impregnated Clinoptilolite Zeolite Catalyst to Increase Octane Number in Gasoline
}

\author{
Eny Kusrini ${ }^{1 *}$, Yan Mulders Togar ${ }^{1}$, Vino Hasyim ${ }^{1}$ and Anwar Usman ${ }^{2}$ \\ ${ }^{1}$ Department of Chemical Engineering, Faculty of Engineering, Universitas Indonesia, 16424 Depok, Indonesia \\ ${ }^{2}$ Department of Chemistry, Faculty of Science, Universiti Brunei Darussalam, Jalan Tungku Link, Gadong BE1410, Negara Brunei \\ Darussalam
}

\begin{abstract}
In the present work, the role of praseodymium oxide as a promotor of active site in zeolite base as catalyst for increasing the octance number in gasoline were investigated. In this study, we used three types of catalyst, namely the activated clipnotilolite zeolite (catalyst 1 ), $\mathrm{Pr}_{6} \mathrm{O}_{11}$-impregnated clinoptilolite zeolite 0.01 (w/w\%) (catalyst 2) and $\mathrm{Pr}_{6} \mathrm{O}_{11}$-impregnated clinoptilolite zeolite 0.1 (w/w\%) (catalyst 3). Both catalyst 2 and 3 were prepared by impregnation method. The calcination temperature for all of catalysts was set at $500^{\circ} \mathrm{C}$ for 2 hours to remove the organic impurities and stabilize the structure of catalyst. The Si/Al ratio increased from 5.1 to 5.85 with prasedymium nitrate hexahydrate percentage in catalysts 2 and 3 were 0.14 and $0.05 \%$, respectively. The surface area of catalysts $1-3$ are $19.42,18.09$ and $15.22 \mathrm{~m}^{2} / \mathrm{g}$, respectively. The activity performance of catalyst 3 with 1 and $3 \%$ loading at $27.7^{\circ} \mathrm{C}$ for 2 min have increased the octane number of 0.1 . Increasing octane number of 0.1 was also confirmed by GC-MS data which showed the presence of decreasing $\mathrm{C}_{4}-\mathrm{C}_{11}$ hydrocarbon compounds and increasing of aromatic compounds. $\mathrm{Pr}_{6} \mathrm{O}_{11}$-impregnated clinoptilolite zeolite catalyst is potential for application in fuel system to increase octane number at room temperature $\left(27.7^{\circ} \mathrm{C}\right)$.
\end{abstract}

\section{Introduction}

Octane number is an indicator that shows the ability of gasoline to produce maximum power from machine and can hold knocking condition on the time of ignition fuel. It depends on the hydrocarbon type; some additives were used to increase the octane number gasoline such as methanol, ethanol, tetraethyl lead (TEL, $\left.\mathrm{Pb}\left(\mathrm{C}_{2} \mathrm{H}_{5}\right)_{4}\right)$, methyl tertiary butyl ether $\left(\mathrm{MTBE},\left(\mathrm{C}_{5} \mathrm{H}_{11} \mathrm{O}\right)\right)$, tertiary butyl alcohol (TBA), tert-amyl methyl ether (TAME), and tertiary butyl formate (TBF) [1]. They were used to improve efficiency of the flame and combustion and stabilize the fuel mixture. However, the presence of additive compound induced the toxic properties and result in the carcinogenic, thus it is limited used. Therefore, it is necesarry to synthesis catalyst or additive materials which were safe, economical, environmental friendly, and had a simple method.

Effective catalyst should at least have the good selectivity, activity, and durability and can produced the desired product in operating conditions that are not too extreme. To produce an effective catalyst, the role of support as the spread of the active site can increase the overall effectiveness of the catalyst. The support catalyst must have the structure which can be dispersed on the active site so that it can multiply the different number of active site on the surface catalyst.

We selected the clipnotilolite zeolite as support catalyst based on the large surface area, stable at high temperature, high acidity properties and suitable for using in cracking process of compounds. Another advantages of natural zeolite is its existence of large quantities in nature, low price, and has a hole structure of pore size. The modification of activated clinoptilolite zeolite by praseodymium oxide was expected to minimize the nature zeolite from mineral contents as dopants, to increase the surface area, and to provide the active site of acid form [2]. The use of rare earth elements for fluid catalytic cracking [3] and the overall activiy of the catalyst has been reported by Sousa-Aguiar et al. [4].

The impregnation method is well-known in the catalyst industry because its simple and relatively easy [5]. Praseodymium nitrate hexahidrate was calcined at $500^{\circ} \mathrm{C}$ for $2 \mathrm{~h}$ to obtain stable crsytal of Praseodymium oxide, namely $\operatorname{Pr}_{6} \mathrm{O}_{11}$ [6]. The role of $\operatorname{Pr}_{6} \mathrm{O}_{11}$ in the catalyst was as active site on catalyst. As a catalyst, $\mathrm{Pr}_{6} \mathrm{O}_{11}$ exhibits good activity performance during the oxidative coupling of methane [7]. At the same period, praseodymium oxide, $\operatorname{Pr}_{6} \mathrm{O}_{11}$, exhibits the highest yield for the synthesis of ethane and ethylene from methane and carbon dioxide [8]. The experiment using praseodymium nitrate hexahydrate modifed zeolite has also been carried out in cracking hydrocarbon process in gasoline. The results showed an increase in the octane number of gasoline of by a factor of 1.6 , indicating that long chain hydrocarbon was cracked to either short chain or branched hydrocarbons. Furthermore, praseodymium

Corresponding author: ekusrini@,che.ui.ac.id 
oxide have been introduced into solid clipnotilolite zeolite to increase surface area.

In this study, synthesis of $\operatorname{Pr}_{6} \mathrm{O}_{11}$-impregnated clinoptilolite zeolite and its application as catalyst to increase the octane number in gasoline was investigated. To find out the effect of $\operatorname{Pr}_{6} \mathrm{O}_{11}$ as active sites to increase the octane number, the concentration of Pr was varied. At the first, the modification of clinoptilolite zeolite with $\operatorname{Pr}$ is studied. The gasoline system before and after containing $\operatorname{Pr}_{6} \mathrm{O}_{11}$-impregnated clinoptilolite zeolite as a catalyst are evaluated in details.

\section{Experimental}

2.1 Preparation of $\operatorname{Pr}_{6} \mathrm{O}_{11}$-impregnated clinoptilolite zeolite

Natural clinoptilolite with particle size of 200 mesh (74 $\mu \mathrm{m})$ was obtained from Lampung (Indonesia). The modification process of natural zeolite by ion exchange process with acid treatment, calcination, and impregnation of praseodymium nitrate hexahydrate salt. Basically, the acid treatment process used to increase the $\mathrm{Si} / \mathrm{Al}$ ratio. In acid treatment solutions of $\mathrm{HCl} 0.05 \mathrm{M}$, $\mathrm{NaOH} 0.05 \mathrm{M}, \mathrm{NaCl}$ and $\mathrm{NH}_{4} \mathrm{OH} 0.05 \mathrm{M}$ to produce activated clinoptilolite zeolite (catalyst 1) were used. Calcination was carried out by blowing air at $400^{\circ} \mathrm{C}$ for $4 \mathrm{~h}$ to obtain the catalyst 1 which is expected to be stable at high temperatures.

Praseodymium nitrate hexahidrate compounds with various concentrations; 0.01 and $0.1 \%(\mathrm{w} / \mathrm{w})$, were mixed with activated clipnotilolite zeolite (catalyst 1) by using impregnation method. The mixture was stirred and heated at $60^{\circ} \mathrm{C}$ for $1 \mathrm{~h}$. The mixture then was heated at $105^{\circ} \mathrm{C}$ in oven to remove water content to obtanied the dehydrated Pr/zeolite. Finally, the solid was transferred to a muffle furnace and calcined at $500^{\circ} \mathrm{C}$ for $2 \mathrm{~h}$. The powder, which is the final product of praseodymium oxide/clinoptilolite zeolites (catalysts 2 and 3 ) were subjected for characterizations and catalyst experiments.

\subsection{Characterization}

The catalysts were characterized by Brunauer, Emmett and Teller (BET), Scanning Electron Microscope-Energy Dispersive Spectroscopy (SEM-EDS), X-ray Diffraction (XRD), dan Fourier Transform Infrared (FTIR) spectroscopy.

The performance of catalysts was evaluated at temperatures of $22.7,40$, and $60^{\circ} \mathrm{C}$, and times of 2,10 , and $60 \mathrm{~min}$ with gasoline volume of $400 \mathrm{~mL}$. The final product was characterized using FTIR, GC-MS and portable octane number. The activity test of products was calculated by conversion and selectivity the following using equations:

Hydrocarbon conversion of $\mathrm{C}_{4}-\mathrm{C}_{6}, \mathrm{C}_{7}-\mathrm{C}_{8}$ and $\mathrm{C}_{11}-\mathrm{C}_{12}$;

$X_{i}=\frac{F_{i}^{o}-F_{i}}{F_{i}^{O}}$

Cracking product selectivity of $\mathrm{C}_{4}-\mathrm{C}_{6}, \mathrm{C}_{7}-\mathrm{C}_{8}$ and $\mathrm{C}_{11^{-}}$ $\mathrm{C}_{12}$;
$S_{i}=\frac{F_{i}-F_{i}^{O}}{\sum F_{i}-\sum F_{i}^{o}}$

where $\sum F_{i}-\sum F_{i}^{o}$ for $F_{i}>F_{i}^{o}$.

\section{Results and Discussion}

\subsection{Activation of Clinoptilolite Zeolite}

For natural zeolite, the presences of water molecules inside pores and free oxide on the surface, such as $\mathrm{SiO}_{2}$, $\mathrm{Al}_{2} \mathrm{O}_{3}, \mathrm{CaO}, \mathrm{MgO}, \mathrm{Na}_{2} \mathrm{O}, \mathrm{K}_{2} \mathrm{O}$ covered the pores of zeolite or active site were observed. Practically, they can reduce the adsorption capacities and catalytic properties of zeolite [9]. Therefore, it was the reason to activate the zeolite before it is used as catalyst. Usually chemical activation was carried out by washing the zeolite using aquadest, $\mathrm{HCl}$ solution, $\mathrm{NaOH}$ solution, $\mathrm{NaCl}$ saturated solution, and $\mathrm{NH}_{4} \mathrm{OH}$ solution to remove the impurities on the pore surface. We found the impurities $(\mathrm{Ca}, \mathrm{Fe}$, and $\mathrm{K}$ ) were reduced after activation (see Table 1). This phenomenon shows that the ability of zeolite in ion exchange depends on the number of cation exchange on zeolite. Zeolite cation could be exchanged with the other cations of alkali metal or alkaline earth, such as $\mathrm{Si}^{4+}$ and $\mathrm{Al}^{3+}$, because the impurities were not bound by four oxygen atoms in the framework zeolite. After the activation, calcination at $400^{\circ} \mathrm{C}$ for $4 \mathrm{~h}$ gave the acid of activated clinoptilolite zeolite.

\subsection{BET Characterization}

Decreasing the spesific surface area of catalyst was caused by growing number of $\operatorname{Pr}_{6} \mathrm{O}_{11}$ metal onto the solid surface of the clinoptilolite zeolite (see Table 1). This is due to the amount of $\operatorname{Pr}_{6} \mathrm{O}_{11}$ metal increased, thus the probability of its diffusion into the opening of pore increased. It will be accumulated in some pores and covered them. This phenomenon was observed in catalyst 3 , where surface area decreased to $15.22 \mathrm{~m}^{2} / \mathrm{g}$. It is slightly smaller than that of clinoptilolite zeolite $(18.5$ to $15.7 \mathrm{~m}^{2} / \mathrm{g}$ ) previously reported by Kusrini et al. [11].

Table 1. BET Characterization Result

\begin{tabular}{|c|c|c|c|}
\hline Characteristic & Catalyst 1 & Catalyst 2 & Catalyst 3 \\
\hline $\begin{array}{c}\text { Surface area } \\
\left(\mathrm{m}^{2} / \mathrm{g}\right)\end{array}$ & 19.42 & 18.09 & 15.22 \\
\hline $\begin{array}{c}\text { Pore volume } \\
(\mathrm{cc} / \mathrm{g})\end{array}$ & 0.002251 & 0.0006907 & 0.001113 \\
\hline Pore size $(\AA)$ & 17.6 & 17.88 & 17.6 \\
\hline
\end{tabular}

\subsection{SEM-EDS analysis}

SEM images of activated clipnotilolite zeolite before and after modification with $\mathrm{Pr}(\mathrm{N} \mathrm{O}(3) \mathrm{m}) \cdot 6 \mathrm{H}_{2} \mathrm{O}$ are depicted in Figure 1. The catalyst have a size ranging from 1.33 to $2.59 \mu \mathrm{m}$. The catalyst 1 is the biggest size and catalyst 3 is the smallest because of the large number of $\mathrm{Pr}$ 
impregnation onto surface of zeolite. Thus, the latter was able to give a good effect on performance activity test of catalyst.

$\mathrm{Pr}_{6} \mathrm{O}_{11}$ content in catalyst 2 was by $0.14 \%$ and the catalyst 3 was by $0.05 \%$. It indicated that $\operatorname{Pr}$ was successfully impregnated into the pore of zeolite. According the Table 2, by comparing percentage of $\mathrm{Si} / \mathrm{Al}$ ratio, the obtained value of $\mathrm{Si} / \mathrm{Al}$ ratio catalyst 1,2 , and 3 are 5.67, 5.85, and 5.18, respectively. Based on value of acidity catalyst were expected, catalyst 1,2 , and 3 can provide the good perfomance to crack hydrocarbons in gasoline with better quality.
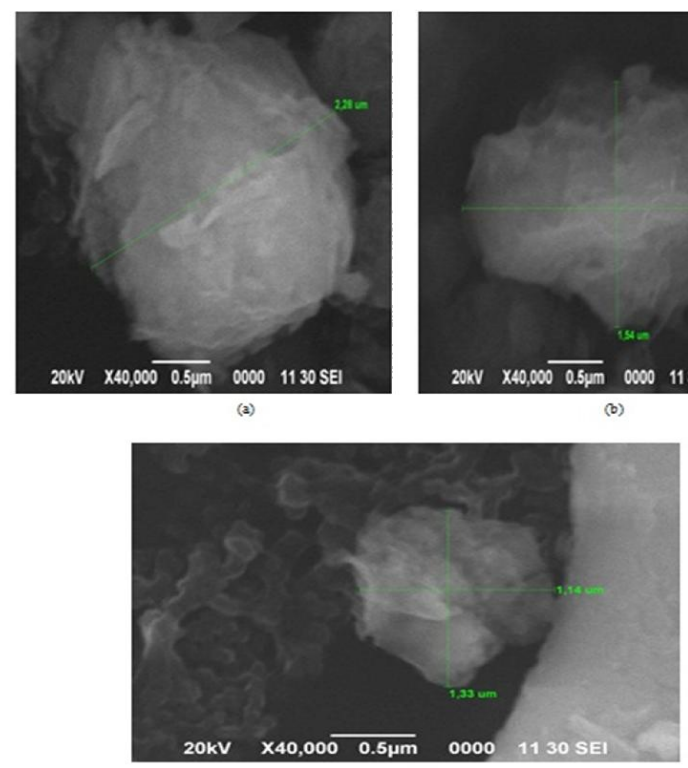

Fig 1. SEM images of (a) Catalyst 1, (b) Catalyst 2, (c) Catalyst 3

Table 2. EDS Composition

\begin{tabular}{|c|c|c|c|c|}
\hline \multirow{2}{*}{ Element } & \multicolumn{4}{|c|}{ mass (\%) } \\
\cline { 2 - 5 } & $\begin{array}{c}\text { Unmodifed } \\
\text { zeolite }\end{array}$ & Catalyst 1 & $\begin{array}{c}\text { Catalyst } \\
2\end{array}$ & $\begin{array}{c}\text { Catalyst } \\
3\end{array}$ \\
\hline $\mathrm{O}$ & 46.54 & 41.21 & 43.44 & 47.1 \\
\hline $\mathrm{Mg}$ & 1.01 & 0 & 0.84 & 0.87 \\
\hline $\mathrm{Al}$ & 6.58 & 7.4 & 6.45 & 6.83 \\
\hline $\mathrm{Si}$ & 33.56 & 42.02 & 37.73 & 35.38 \\
\hline $\mathrm{K}$ & 2.88 & 2.95 & 1.85 & 1.93 \\
\hline $\mathrm{Ca}$ & 4.38 & 0 & 1.29 & 1.22 \\
\hline $\mathrm{Fe}$ & 5.06 & 1.19 & 1.64 & 1.31 \\
\hline $\mathrm{Na}$ & 0 & 3.22 & 3.14 & 2.77 \\
\hline $\mathrm{Cl}$ & 0 & 2.02 & 2.35 & 1.47 \\
\hline $\mathrm{Zn}$ & 0 & 0 & 1.13 & 1.07 \\
\hline $\mathrm{Pr}$ & 0 & 0 & 0.14 & 0.05 \\
\hline
\end{tabular}

\subsection{XRD Characterization}

In general, $2 \theta$ angle of XRD pattern at $20^{\circ}-30^{\circ}$ showed as the typical for clipnotilolite zeolite. The sharp peak was interpret that clipnotilolite zeolite contained $\mathrm{SiO}_{2}$ and $\mathrm{Al}_{2} \mathrm{O}_{3}$ [10], which are the main characteristic from zeolite. After modification with $\operatorname{Pr}_{6} \mathrm{O}_{11}$ similar peaks at
$27-31^{0}$ and $38-41^{0}$ (Figure 2) were observed. This indicated that impregnation and calcination of prasodymium nitrate hexahidrate to produce the praseodymium oxide $\left(\operatorname{Pr}_{6} \mathrm{O}_{11}\right)$ has been successfully obtained.

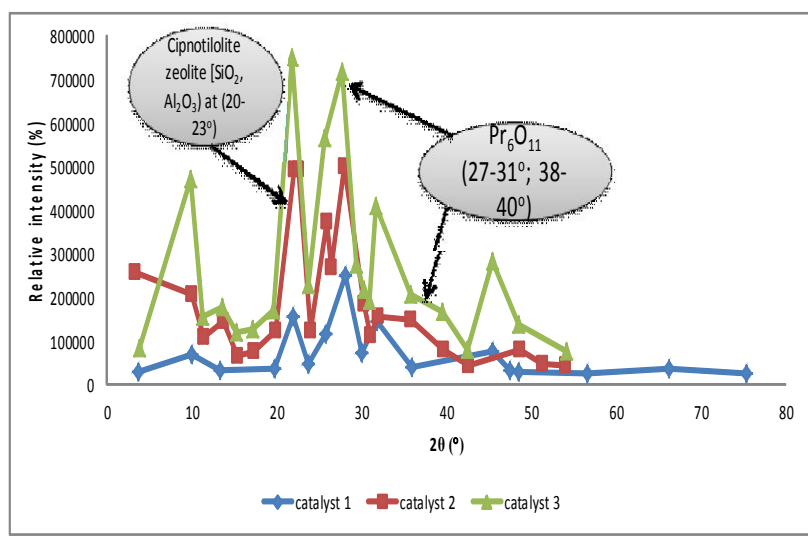

Fig 2. XRD patters of (a) Catalyst 1, (b) Catalyst 2, (c) Catalyst 3

\subsection{FTIR studies}

The main characteristic of clinoptilolite zeolite is asymetric stretch and double ring group of O-Si-O and $\mathrm{O}-\mathrm{Al}-\mathrm{O}$ at $1040 \mathrm{~cm}^{-1}$ and $599 \mathrm{~cm}^{-1}$, respectively. This presence of his interpretation shows that the zeolite contains $\mathrm{Si}, \mathrm{O}$, and $\mathrm{Al}$ elements, as the SEM-EDX characterization. In addition, there are $\mathrm{NH}_{4}^{+}$region at $1389 \mathrm{~cm}^{-1}$, which showed that quantitatively there has been ion exchange between $\mathrm{NH}_{4} \mathrm{OH}$ and activated clipnotilolite zeolite. According to Tanabe [12] interaction of peak absorption pyridine with Bronstead acid sites appeared at 1447-1460, 1488-1503, 1580, and $1600-1633 \mathrm{~cm}^{-1}$, whereas the interaction of pyridine with Lewis acid sites appeared at 1447-1460, 1488-1503, $\sim 1580$, dan $1600-1633 \mathrm{~cm}^{-1}$, and the interaction of pyridine with hidrogen bond was appeared at 1400-1447, $1485-1490$ and $1580-1600 \mathrm{~cm}^{-1}$.

Changing of absorption peak was observed for catalyst 1 at $1635 \mathrm{~cm}^{-1}$, to a new region, which is 1649 $\mathrm{cm}^{-1}$ for catalyst 2 . This changing can be estimated due to differences strength of Bronstead acid as consequently the forming praseodymium oxide, $\operatorname{Pr}_{6} \mathrm{O}_{11}$ on clinoptilolite zeolite surface [6]. This is in agreement with the presence of new peaks at $2 \theta$ angles of $27-31^{\circ}$ and $38-40^{\circ}$. The presence of a new peak increased the acidity of the catalyst, which showed by increasing $\mathrm{Si} / \mathrm{Al}$ ratio. Accordingly, SEM-EDX analysis shows a reduction of $\mathrm{Al}^{3+}$ ions. It indicated that impregnation of praseodymium oxide as $\operatorname{Pr}^{3+}$ ions has successfully replaced $\mathrm{Al}^{3+}$ ion, increasing its acidic ratio than catalyst 1. The absorption band at $1396 \mathrm{~cm}^{-1}$ indicated the characteristic of pyridine hydrogen bond. Increasing the intensity of absorption region confirmed the increase in the Bronstead acid properties for catalyst 2 . 


\subsection{Catalyst performance}

Table 3 shows that the activity performance of catalyst 1 - 3. It indicated the presence of addition long chain hydrocarbon and less branched chain hydrocarbon. The existence of them have had low octane number and gaining of the compounds. Increasing octane number was influenced by the amount of branched or short chain hydrocarbon and the presence of alcohol or aromatic groups [13]. Thus, the research was conducted at 27.7 ${ }^{\circ} \mathrm{C}$, time of 2 min, and $\%$ loading catalyst 3 is 1 and $3 \%$, and gasoline volume is $400 \mathrm{~mL}$.

Table 3. Experimental for catalyst performances to increase octance number in Gasoline

\begin{tabular}{|c|c|c|}
\hline \multicolumn{3}{|c|}{$\begin{array}{c}\text { Exp. 1: Temperature at } 60^{\circ} \mathrm{C}, t=60 \mathrm{~min}, 0.1 \% \\
\text { loading catalyst }\end{array}$} \\
\hline Catalyst & BO & $\begin{array}{c}\text { Delta } \\
\text { BO }\end{array}$ \\
\hline Gasoline & 91 & 0 \\
\hline Gasoline + Catalyst 1 & 90.4 & -0.6 \\
\hline Gasoline + Catalyst 2 & 90.8 & -0.2 \\
\hline Gasoline + Catalyst 3 & 90.4 & -0.6 \\
\hline \multicolumn{3}{|c|}{$\begin{array}{c}\text { Exp. 2: Temperature at } 60^{\circ} \mathrm{C}, t=10 \mathrm{~min}, 0.1 \% \\
\text { loading Catalyst }\end{array}$} \\
\hline Catalyst & $\mathrm{BO}$ & $\begin{array}{c}\text { Delta } \\
\text { BO }\end{array}$ \\
\hline Gasoline & 89.7 & 0 \\
\hline Gasoline + Catalyst 1 & 89.3 & -0.4 \\
\hline Gasoline + Catalyst 2 & 89.5 & -0.2 \\
\hline Gasoline + Catalyst 3 & 89.3 & -0.4 \\
\hline \multicolumn{3}{|c|}{ Exp. 3: Temperature at $40^{\circ} \mathrm{C}$, Catalyst $2, t=2 \mathrm{~min}$} \\
\hline$\%$ loading Catalyst & $\mathrm{BO}$ & $\begin{array}{c}\text { Delta } \\
\text { BO }\end{array}$ \\
\hline Gasoline & 89.4 & 0 \\
\hline 0.5 & 89.4 & 0 \\
\hline 1 & 89.4 & 0 \\
\hline 1.75 & 89.3 & -0.1 \\
\hline 3 & 89.4 & 0 \\
\hline \multicolumn{3}{|c|}{ Exp. 4: Temperature at $27.7^{\circ} \mathrm{C} t=2 \mathrm{~min}$} \\
\hline Catalyst & $\mathrm{BO}$ & $\begin{array}{c}\text { Delta } \\
\text { BO }\end{array}$ \\
\hline Gasoline & 89.4 & 0 \\
\hline $1 \%$ Catalyst 3 & 89.5 & 0.1 \\
\hline $3 \%$ Catalyst 3 & 89.5 & 0.1 \\
\hline
\end{tabular}

It is believed that the mechanism of cracking reaction is via the formation of carbonium ions. Each new carbonium ions induced other compounds to form new carbonium ions by the short number of hydrocarbons, so that the dominant product produced was hydrocarbon compound with a small number of carbon atoms. Addition of $\operatorname{Pr}_{6} \mathrm{O}_{11}$ in activated clinoptilolite zeolite improved the activity of catalyst in cracking reaction. A high conversion and selectivity product formed $\mathrm{C}_{4}-\mathrm{C}_{6}$ and $\mathrm{C}_{7}-\mathrm{C}_{8}$, while the hydrocarbon chains of $\mathrm{C}_{11}-\mathrm{C}_{12}$ was significantly decreased. It is showed by $100 \%$ conversion of $\mathrm{C}_{11}-\mathrm{C}_{12}$ was to form short hydrocarbon chains and/or short carbonium ions and/or new hydrocarbon groups. This data was confirmed by GCMS data.

The absorption band of hydroxyl group was observed at 3646 and $3667 \mathrm{~cm}^{-1}$. The aliphatic hydrocarbon compounds was formed from combination of long-chain hydrocarbon and these were observed at 2925; 2957; $1455 ; 728$ and $768 \mathrm{~cm}^{-1}$. Frequencies was shifted about $20 \%$. Catalyst 3 can crack the long-chain hydrocarbon compounds similar to that observed for catalytic performance of HZSM-5 zeolite for cracking of butane to light olefins [14].

Absorbance of the aromatic bond appeared on the FTIR analysis. The absorption bands that assigned for benzene groups with the $\mathrm{C}=\mathrm{C}$ groups at $1580-1615 \mathrm{~cm}^{-1}$ and $\mathrm{C}-\mathrm{H}$ bands at $670-900 \mathrm{~cm}^{-1}$ has been observed upon the addition of aromatic bonds for treatment of gasoline using catalyst 3 . The presence of new peaks at 1651 and $1682 \mathrm{~cm}^{-1}$ is followed by the disappearance of peak at $1614 \mathrm{~cm}^{-1}$. It is indicated that the catalytic cracking reaction produced more the aromatic group after the addition of catalyst 3 . This phenomenon occured because of the acidity strength of catalyst 3 for cracking reaction. In addition, the absorption band at 1620-1680 $\mathrm{cm}^{-1}$ was also indicated the presence of cluster $\mathrm{C}=\mathrm{C}$ on the alkene compounds. However, in this study, we found that there is a tendency that the $\mathrm{C}=\mathrm{C}$ aromatic compound are more dominant than alkenes.

Figures 3 and 4 showed the effect of performance catalyst 3 for cracking reaction. The number of branched hydrocarbon chains, aromatics, alcohols, and oxygenate compounds before and after treatment with catalyst 3 were observed clearly. The optimum operating conditions for catalyst performance using catalyst 3 was set at temperature of $27.7^{\circ} \mathrm{C}$, time of $2 \mathrm{~min}$, and loading catalyst of 1 and 3\%. Increasing octane number of 0.1 indicated by the presence of short chain aliphatic compound, alcohol, aromatic, which has a higher octane number.

Based on the thermodynamic properties, the Gibbs energy value was presented. The Gibbs energy equation can be expressed as follows:

$\Delta G=-R T \ln K$

If the $\Delta \mathrm{G}<0$, or the value was negative, then the reaction occur spontaneously, it means that the energy conversion will large because the value of the equilibrium constant of $K$ was large. Conversely, if $\Delta G>$ 0 , or the value was positive, then the reaction occur is not spontaneously, it implies that the energy conversion happens in small as well as the value of the equilibrium constant of $\mathrm{K}$ was relatively small.

From the results of GC-MS analysis, we assumed some reactions may occur as follows. It can be concluded that the reaction can occur spontaneously when introducing catalyst in gasoline. In this case, the Gibbs energy is negative value and value of the equilibrium constant $\mathrm{K}$ is large, thus the product is greater than the number of the reactants from the test results of activity of the catalyst.

The formation of $\mathrm{n}$-heptane and cyclobutane as product from undecane as reactan. 
$\mathrm{C}_{11} \mathrm{H}_{24} \rightarrow \mathrm{C}_{7} \mathrm{H}_{16}+\mathrm{C}_{4} \mathrm{H}_{8}, \Delta \mathrm{G}_{298,15 \mathrm{~K}}=-21,1 \mathrm{~kJ} / \mathrm{mol}$ The formation of n-pentane and n-hexane as product from undecane as reactan.

$\mathrm{C}_{11} \mathrm{H}_{24} \rightarrow \mathrm{C}_{5} \mathrm{H}_{12}+\mathrm{C}_{6} \mathrm{H}_{12}, \Delta \mathrm{G}_{298,15}=-5,2 \mathrm{~kJ} / \mathrm{mol}$

The formation of ethylbenzene and n-butane as product from cyclohexane as reactan.

$2 \mathrm{C}_{6} \mathrm{H}_{12} \rightarrow \mathrm{C}_{8} \mathrm{H}_{10}+\mathrm{C}_{4} \mathrm{H}_{10}+2 \mathrm{H}_{2}, \Delta \mathrm{G}_{298,15}=$ $-22,7 \mathrm{~kJ} / \mathrm{mol}$

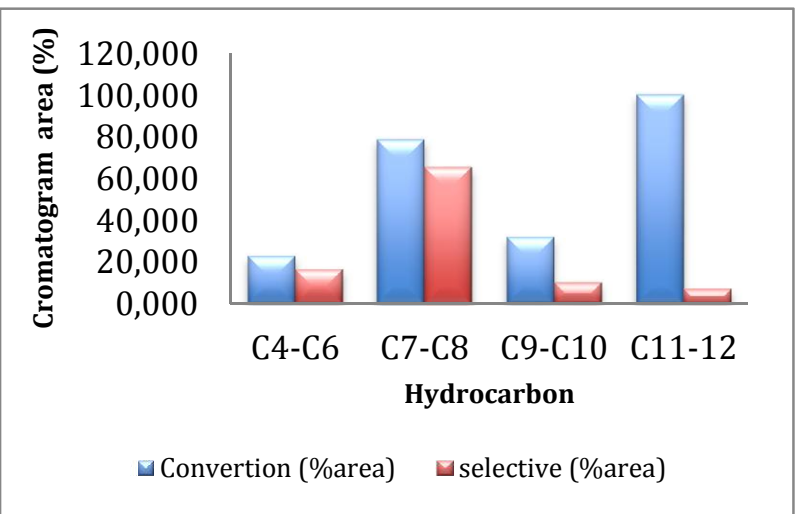

Fig 3. Hydrocarbons Conversion and Selective of hydrocarbon in Gasoline, Before and After treatment using Catalyst 3

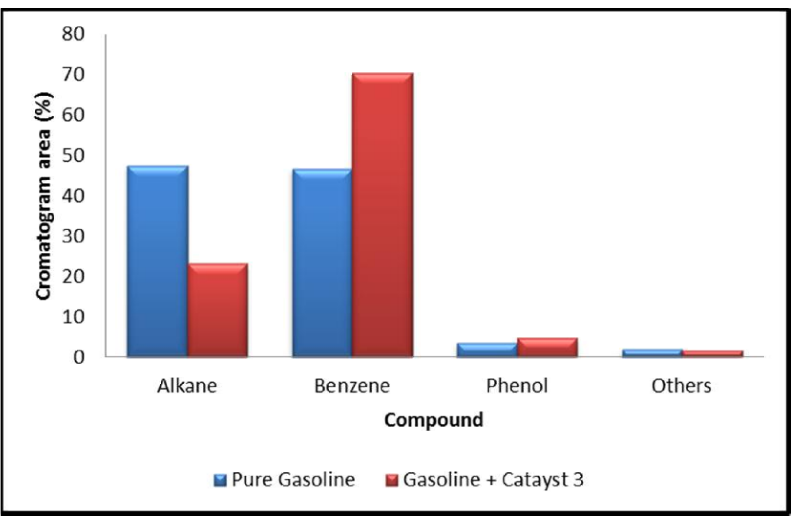

Fig 4. Comparison of Composition Compounds Before and After treatment using catalyst 3 in Gasoline

\section{Conclusion}

Praseodymium oxide modified activated clinoptilolite zeolite $\left(\operatorname{Pr}_{6} \mathrm{O}_{11}\right.$-impregnated clinoptilolite zeolite) catalysts were synthesized and applied as catalyst to increase the octane number of gasoline. $\operatorname{Pr}_{6} \mathrm{O}_{11^{-}}$ impregnated clinoptilolite zeolite catalyst was synthesized by impregnation method. Based on BET characterization, the reducing of specific surface area of the catalyst was observed from 19.42 to $15.22 \mathrm{~m}^{2} / \mathrm{gr}$ which showed by increasing number of $\mathrm{Pr}_{6} \mathrm{O}_{11}$ on the surface of clipnotilolite zeolite. The ratio of $\mathrm{Si} / \mathrm{Al}$ catalyst were in the range of 5.18 to 5.85 . The use of a catalyst of $0.1 \% \operatorname{Pr}_{6} \mathrm{O}_{11}$-impregnated clinoptilolite zeolite with mass variations of 1 and $3 \%$ catalyst loading to the $400 \mathrm{~mL}$ of gasoline, at temperature of $27.7^{\circ} \mathrm{C}$ and time for 2 minutes, the octane number of gasoline increase of 0.1 . The increase in the octane number was caused by the cracking and/or reduction of hydrocarbon long

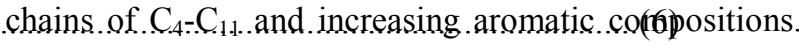
$\operatorname{Pr}_{6} \mathrm{O}_{11}$-impregnated clinoptilolite zeolite catalyst is potential for application in fuel system to increase octane

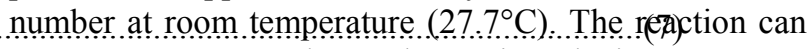
occur spontaneously when introducing $\operatorname{Pr}_{6} \mathrm{O}_{11^{-}}$ impregnated clinoptilolite zeolite catalyst in gasoline.

The authors greatly acknowledge the Universitas Jedonesia as financial support through "Multidiscipline... Grant No. 1650/UN2.R12/HKP.05.00/2015”.

\section{References}

[1] S.S. Kish, A. Rashidi, H.R. Aghabozorg, L. Moradi, Applied Surface Science 256, 3472-3477 (2010).

[2] Riberio. F. Zeolites: Science and Technology. Netherland: NATO Advances Studies Institute, Martinus Nijhof Publisher (1984).

[3] A. Akah, Journal of Rare Earths 35, 941-956 (2017).

[4] E.F. Sousa-Aguiar, F.E. Trigueiro, F. M. Z. Zotin, Catalysis Today 218-219, 115-122 (2013).

[5] Campanati, M., G. Fornasari, A. Vaccari. Catalyst Journal 77, 299-314 (2003).

[6] Hussein, G.A.M. Thermochimica Acta 369, 59-66 (2001).

[7] S. Sugiyama, T. Miyamoto, H. Hayashi, M. Tanaka, J.B. Moffat, J. Mol. 1997. Catalyst A 118: 129-136.

[8] K. Asami, K. Kusakabe, N. Ashi, Y. Ohtsuka. Applied Catalyst. A 156, 43-56 (1997).

[9] Hasyim, V. 2011. Peningkatan Bilangan Oktanan pada Gasoline Menggunakan Praseodimium oksidaEtilen Diamin Tetra Asetat/Zeolit Klipnotilolit Aktif. Teknik Kimia. Depok, Universitas Indonesia. Sarjana Teknik.

[10] Muthia, R. 2010. Peningkatan Bio-Oil dari Tandan Kosong Kelapa Sawit Menggunakan Metode Fast Pyrolysis dengan Katalis Zeolit. Depok: Universitas Indonesia.

[11] E. Kusrini, A. Usman, J. Wibowo, Arabian Journal for Science and Engineering, Published, 1 - 9 (2018).

[12] Tanabe, K. 1981. "Solid Acid and Base Catalyst in Catalysis Science and Technology", John R Anderson and Michael Boudart (eds) Vol. 2, Springer-Link Berlin, 231-273.

[13] Liu, C. Applied catalyst A: Chemical 215 195-199 (2004)

[14] W. Xiaoning, Z. Zhen, X. Chunming, D. Aijun, Z.Li, J. Guiyuan, Journal of Rare Earths 25, 321 - 328 (2007) 